\title{
Dealing with COVID-19 in the European periphery: between securitization and "gaslighting"
}

\author{
Biljana Vankovska ${ }^{1}$
}

\begin{abstract}
The objective of this paper is to outline and analyse the manner in which governments on the EU's south-eastern periphery (i.e. the Western Balkans) responded to the COVID-19 pandemic and its possible after-effects. The author seeks to shed light on three particular aspects of the crisis: the (de)securitization process of COVID-19, the geopolitics of the EU enlargement process in the post-corona world, and the Balkan way of dealing with the pandemic. Following a prologue that tries to decipher what is behind the façade of this dramatic episode, the article proceeds to characterize both the securitization of COVID-19 and the "gaslighting turnaround". It then looks at the Balkan version of the so-called "COVID-1984", i.e. the autocratic tendencies that have blossomed amid (and thanks to) strong security concerns.
\end{abstract}

Keywords: COVID-19, Western Balkans, EU, disaster capitalism

The central premise is that although the current crisis seems to have been provoked by the spread of an unprecedented disease, COVID-19 is not its root cause. The "invisible enemy" has just made the dreadful features of "disaster capitalism" more visible (and even palpable through its death toll). The pandemic is already being (mis)used as a smokescreen for precarious developments advertized as the "new normalcy". While at first sight its immediate and strongest effects seem to have spared the geopolitical periphery (as was also the case with the financial crisis of 2008), history teaches us this is exactly where ruptures happen.

\section{Prologue}

COVID-19 lost no time in finding a place in newspaper lexicons the world over. The same applies to many other words/concepts related to it: COVID-geopolitics, COVID-diplomacy, war against COVID-19, COVID-19(84), etc. Another vastly accepted phrase is "new normalcy", which raises alarm when heard from political elites in charge of crisis management. The propaganda war over the origin of COVID-19 shapes public opinion on a global level, which only confirms the relevance of the old saying that a war's first victim is truth. Its consequences may be grave in terms of re-shaping the global order.

COVID-capitalism is nothing new; it is just a new stage in the development of disaster capitalism - and maybe the last phase of capitalism itself, as many on the Left are hoping (though they still struggle to articulate a viable alternative). Voices from all sides of the political spectrum, speaking on behalf of both the richest $1 \%$ and the rest of the population, are heard clamouring that a crisis like this "must not be wasted". There is a pretence that the hitherto dominant TINA mantra (There Is No Alternative - to the neoliberal/ordoliberal order) is now an object of re-consideration by the Left and Right alike. Leftist and critical circles have seen an opportunity to open a "portal" to another (better) world, ${ }^{2}$ while neoliberal status quo forces try to capitalize on this God-given opportunity to strengthen their grip on national and global rule. A most important (but little addressed) question reads: who is going to engage in this post-pandemic re-building or transformation of the world? Yet, few 
of these issues are on the table in the Western Balkans, where apart from the ongoing public health challenges and concerns, everything remains as if the world had not changed in a matter of weeks.

Globally, the COVID-19 pandemic came at a critical moment of soul-searching. It could be best illustrated by the old joke about what separates pessimists from optimists: to the pessimist's claim that "it can't get worse", the optimist responds: "yes, yes, it can". Gramsci's famous quote - "pessimism of the intellect, optimism of the will" - only helps if one does not give up even in the worst of times. The difference between a life without illusions and one full of disillusionment becomes apparent and useful only if the reality at hand is analysed with eyes wide open - and if the truth is told no matter what the consequences. Easier said than done; truth has scarce currency in the so-called post-truth world, and the inflation of contradictory news or analyses makes it even harder to distillate it from the halftruths that circulate widely.

The widespread sentiment that the world will never be the same again irresistibly echoes the 9/11 moment. Indeed, the post-9/11 world did not bring anything better on either the international or local level. Human rights and freedoms fell victim to enhanced security measures and fearmongering. It may be too early to predict what the post-COVID world will look like but the lessons (un)learned raise concerns. While some nostalgically dream of going back to the "good old days" of normalcy as we knew it, others are more concerned with what is dubbed "new normalcy". This phrase so far resembles an empty container that may be filled in with different contents and few are able to predict what "new" good it might bring to the world and societies. The cries for a better world that, by default, followed past grave crises regularly dried out rather quickly, like desert blossoms after a rainy day. The aftermath of the First and Second World Wars proves the point, just as does the (alleged) end of the Cold War. It is a bare fact that the world (and individual States) still live under the structural violence embedded by the effects of neoliberalism, where the most vulnerable sections of the population are disproportionately affected. ${ }^{3}$ During the pandemic and the lockdown measures it entailed, that part of population was even more exposed to health risks. ${ }^{4}$ The vulnerability has always been there among the least advantaged people (be they "essentials", Blacks, women, or people with comorbidities such as diabetes, obesity, or other conditions); in death cases among them, it will be hard to tell whether they passed away due to socio-economic factors affecting the quality of their lives or whether COVID-19 was to be blamed as the sole "killer".

All issues related to the nature, characteristics and later health effects of infection by the COVID-19 virus form a set of highly legitimate questions. However, such questions are beyond the competence of the general public, mass media and political propagandists. Medical experts and scientists have such an important say in defining what needs to be done that regular or normal politics seems irrelevant. More precisely, politicians have been known to hide comfortably behind trusted apolitical (sic!) medical expertise while they pull the strings from behind the scenes. For the general population's sake, political elites undertake actions that would be hardly imaginable (and even less acceptable) under normal circumstances, especially in democratic societies (though perhaps not in illiberal democracies). No wonder then that the debate over COVID-19 biopolitics was stirred precisely in the country that has suffered most from the pandemic (Italy), where Giorgio Agamben scandalized many by warning against the manifest tendency to use a state of exception as a normal paradigm for government. ${ }^{5}$ While in China the same rigorous measures and lockdown (limited to Wuhan) have remained uncontroversial, nobody in the West wondered as no contradiction was involved: China has always been an autocracy and its government's actions were to be condemned. Things turned out differently when the virus reached "our way of life" and "our (Western) democracy". 
Vol. 7, No. 1, 71-88.

Months after the outbreak of the pandemic, things are far from clearer. Kenneth Burke's comment, "a way of seeing is also a way of not seeing - a focus on object A involves neglect of object B", sounds very reasonable today. ${ }^{6}$ No wonder fearful and anxious people easily fall victim to conspiracy theories. At a time when science is still unable to give quick, credible and clear-cut answers (let alone a cure or vaccine), ${ }^{7}$ attitudes towards the political leadership become highly ambiguous: the State has triumphantly returned to the scene; political elites are inclined to hide their incompetence and ineptness behind the authority of the "white coats" of medical and paramedical staff. The latter have become heroes in societies that had long neglected them but that now treat them as useful political assets.

While the pandemic is ongoing, it is very hard to venture any meaningful estimate of the cultural, political, socio-economic, security and other consequences of the crisis. Amidst highly polarized philosophical and political controversies, one can hardly reject Agamben's claim that fear is a bad counsellor, as it opens our eyes to many things we pretended not to see. ${ }^{8}$ However, while intellectuals, theoreticians and scholars are engaged, mostly on Zoom, in profound and important debates (hardly helpful for the shocked and disempowered public, to paraphrase Naomi Klein), others do not have that luxury. Torn between fears and hopes, struggling to survive in socio-economic, physical and mental terms every passing day, they focus (or are made to focus) solely on the "killer" virus. Despite all the fuss, the problem is not COVID-19 itself. It has never been, and never will be! Viruses, as well as bacteria and other micro-organisms, are part of the natural environment. COVID-19 is not God's punishment nor cosmic justice, but a logical consequence of humans' treatment of natural habitats of the other living beings on the planet. The real problem resides in the State's inability or unwillingness to respond to any serious non-military threat and to put human well-being before profit.

Single-minded preoccupation with the pandemic serves the elites both as a coverup and as a distraction. The pandemic not only conceals the deeper causes of the ongoing crisis of capitalism, but it also suspends any critical (and radical - grassroots) rethinking of reality in the name of (alleged) humanitarian and ethical ideals. ${ }^{9}$ Even the most lucid analysts have joined the chorus: it's not the right time for regular political debates and blame games, now when people die and everyone is under threat we should stand united and obey the health authorities' orders. At the same time, the pandemic serves as an excuse for anything that does not/did not go well in the way the State functions. While the society has been silenced and pacified (out of fear or due to censorship), the virus is being used as a weapon in the foreign policy realm, sanctions against Iran during the pandemic being just one example. At the same time, a war rhetoric becomes convenient for boosting one's political legitimacy and for imposing mass control more easily - i.e. it is biopolitics understood as governmentality. ${ }^{10}$

COVID-19 looks like an excellent opportunity for an unparalleled large-scale social experiment. Thanatos and Eros policies have both shown great power over people's mindsets and behavior, but the debate between their respective proponents is not over yet. There are romanticized versions of a virus whose role is to awaken mankind's conscience but also Brave New World or 1984 versions of the COVID crisis. The former peddles the "democratic nature" of a virus that does not spare anyone on the planet, thus restoring equality among human beings as well as solidarity between them (from balconies). Such views are either exaggerated or naive - because the global threat has not affected rich and poor equally, nor the West and the Rest, etc. Working from home, self-isolation, virtual socializing or conferencing, and even balconies and protection measures are de facto reserved for the privileged and denied to those now regarded (but for how long?) as "essentials". The idea of solidarity failed where it was least expected - in the European Union, and there is little in evidence among the different social strata in each country. ${ }^{11}$ 


\section{Dealing with the crisis the schizophrenic way: between securitization and gaslighting}

The concept of securitization, a staple of the Copenhagen school of security studies, ${ }^{12}$ postulates that security is a speech act, i.e. that it is not necessarily an objective condition. It means that any issue that can successfully be enunciated as an existential threat to something (i.e. a referent object) by securitizing agents (elites and/or those in a position to make their voices heard) may be removed from the political realm and defined as a security issue, thereby helping reproduce the hierarchical conditions and measures that characterize security practices. In other words, once something is securitized, then normal/political means and actions are replaced by security concerns, and extraordinary protection measures can be imposed, and easily justified, without ever being questioned. Barry Buzan, Ole Waever, and Jaap de Wilde argue that

security is the move that takes politics beyond the established rules of the game and frames the issue (...) as an existential threat, requiring emergency measures and justifying actions outside the normal bounds of political procedure. (...) Something is designated as an international security issue because it can be argued that this issue is more important than other issues and should take absolute priority (. . .) that the issue is presented as an existential threat. ${ }^{13}$

And vice versa, "de-securitization" means that an issue is not, or no longer, seen/conceptualized in terms of security; instead, security simply becomes an irrelevant concern (although it may indeed still represent an existential threat). The de-securitization process implies "less security, more politics!"14 - or even total disregard of a (possibly) real threat, for different reasons. During the pandemic, for instance, de-securitization may lead to an extreme situation where other burning issues (such as, for instance, the migrant crisis or famine) vanish from the radar screens as if they were not important or even never existed. Or, as some authors argue, the UN Security Council and the EU have failed to securitize the pandemics and undertake adequate and coordinated security measures on a global or regional level.

Securitization has been used on many occasions, for different causes, on various levels (local, national, global), and with varying degrees of success. One of the latest episodes in which this process has been in evidence is the climate change controversy and the global movement launched by Greta Thunberg. However, the outbreak of COVID-19 prompted some commentators to wittily note that climate change should have used the services of the COVID-19 PR firm in order to achieve swifter and wider effects on public awareness and political action. Indeed, while COVID-19 has very quickly been securitized, there is an ongoing political struggle over the right narrative of COVID-19 and the responses it has elicited, notably around the question: security for whom? ${ }^{15}$ Attempts to frame the pandemic as a threat common to the "citizens of the world" have proved a losing battle. ${ }^{16}$ National security has overshadowed the humanist approach, as the well-being of one's own population/State is the dominant referent object of security. Both securitizing and de-securitizing processes are largely in the hands of national elites. Thus, political leaders (Donald Trump, Emmanuel Macron, Aleksandar Vučić, and even the Macedonian caretaker Prime minister Oliver Spasovski, to mention just a few) use a war-like rhetoric against the invisible enemy when speaking to national audiences. Conversely, authoritarian leaders, such as Brazil's Jair Bolsonaro or Belarus' Alexander Lukashenko, have dismissed the threat and ignored the pandemic, i.e. they have de-securitized the pandemic and, in a most extreme case (Turkmenistan), even banished the word from their vocabulary.

According to Nathan A. Sears, the securitization of COVID-19 in terms of two distinct "referent objects" reflects the political tension between the nation-state in international politics and the changing circumstances that affect the security of human beings all around the world. However, such a simplistic approach does not pay attention to what is hidden. 
Vol. 7, No. 1, 71-88.

The pandemic has uncovered more than two cleavages: the class essence of the securitization and crisis management policies has become visible both within and among individual nationstates. A differentiation between worthy lives and others (though they may be praised as "heroes" and "essential workers") is what the pandemic has revealed without any doubt. Furthermore, the term "international community" (or organized mankind) is an empty phrase and abstract notion; the same applies to the mostly unheard cry for a global cease-fire issued by the UN Secretary General, but also to the lack of elementary solidarity among EU member-states during the crisis. If there is an ongoing process of de-globalization (as argued by some), one should also pose the question of a similar process of de-Europeanization. The general picture is rather grim, and the lack of empathy and solidarity in a time of deadly crisis is best expressed in the following verse:

(...) Limits of empathy as Noah determined

pulls up his ladder the sealed-in elect

to survive, the drowners to drown. ${ }^{17}$

The international order (or organized mature anarchy) has been designed by the mighty powers in such a way as to allow them to use international organizations as they please: when/ how/to what degree they decide to do so. ${ }^{18}$ The post-modern myth about withering nationstates is being seriously challenged by the behavior of the political class in each of them, and of those who preached this fairy tale to the newly independent States on the European periphery. Borders are back within the Schengen zone (at least temporarily), but the impact of selfish national, not least economic, interests seems slated to remain part of the scene a little bit longer. The collusion of interests over the so-called European corona-bonds and the German understanding of the rule of law within the EU only strengthens the impression created by the manner in which the 2015 Greek crisis had been dealt with.

The way the pandemic has been managed has brought to light other ambiguous, inconsistent, or even schizophrenic moves, ranging from harsh securitizing policies to radical de-securitizing positions, i.e. from the claims (based on worst-case scenarios) that COVID-19 calls for strict measures to deal with a catastrophic (or even apocalyptic) threat, to the other extreme of denial, or eventual de-securitizing that frames it as a manageable problem responsive to certain public policy interventions designed to alleviate public fears and loosen the repressive grip. The tension between securitizing and de-securitizing agents only adds to the general confusion: the former usually yield to exaggeration, while the latter downplay the risks. Interestingly, States (supported by mainstream media, experts, and other influential groups in each society) could be seen on both sides of the fence. At the peak of the crisis the public policy measures included not only recommendations on social distancing, hygiene, closing down schools and other public and business activities, but also lockdown, curfew, and data tracking applications - some of which implied certain limitations or even violations of basic human rights and freedoms.

As soon as the costs of lockdown proved unbearable for business interests and the economy in general, public authorities started to reverse course. They did so in manners (dubbed "gaslighting", after a theatre play of the same name, and to the same effect) that gave citizens a sense of being manipulated into doubting their own sanity. Theoretically, a securitization dilemma appears when securitizing one issue in one sector negatively impacts upon another sector, which creates a dilemma for the securitizers as to whether they should securitize the issue or not. Another securitization dilemma occurs when actions taken to securitize a referent object result in an increased threat to that referent object. ${ }^{19}$ Although not fully developed as a theoretical concept, "gaslighting" refers to a process whereby the securitizer figures out that the costs of securitization measures are too high, so that a turnaround recommends itself through mere psychological propaganda and PR manipulation. This implies that the public is to be blamed if it wrongly understood the threat as an 
existential one while it was not the case (i.e. there was no reason for securitization in the first place, and even if there was - now it's over and should be forgotten).

The scientific debate over COVID-19, which has become a central part of the political process of securitization/de-securitization, is contested and removed from the "normal health public policy" domain - it is made part of security policy, or later used as a persuasion ploy at the end of the lockdown period. American director and writer Julio Vincent Gambuto was among the first to anticipate such moves from securitization to de-securitization. In an article published in mid-April 2020, which went viral within hours, he warned readers to "prepare for the ultimate gaslighting", arguing that ...

pretty soon, as the country begins to figure out how we 'open back up' and move forward, very powerful forces will try to convince us all to get back to normal. (That never happened. What are you talking about?). Billions of dollars will be spent on advertising, messaging, and television and media content to make you feel comfortable again. ${ }^{20}$

With regard to the role of science, academics, and experts, Robert Cox, of critical theory fame, and his brilliant dictum "theory is always for something and some purpose", readily come to mind. ${ }^{21}$ Unfortunately, the same applies to medical and pharmaceutical research as well. The lockdown phase-out process leaves an impression that public health has become a second-rate referent object because some other value (the economy) has priority. Trade-offs are nothing unusual, and the most essential one is between liberty and security, but in the climate of uncertainty over the COVID-19 threat, it is between health and wealth. Recession is knocking on the door and elites are weighing the pros and cons - acceptable gains and costs of prolonging the medical/securitizing measures related to the pandemic. Securitization also implies political costs (or benefits) from the acceptance of extraordinary measures.

\section{COVID-19 in the Western Balkans: geopolitical considerations}

For years, the Western Balkan region concept (geographically meaningless, politically and culturally "invented" in the corridors of powers in Brussels and Washington) has been used to signify a buffer zone between Europeans and non-Europeans. The construct initially embraced the countries of former Yugoslavia minus Slovenia, plus Albania, i.e. countries whose not-quite-European populations were to be kept at a distance and receive special, restrictive treatment. Although flexible to some degree (with Croatia eventually becoming a full EU member), the concept has translated into a geopolitical quarantine of sorts. Especially since the 2015-16 migrant crisis, the region has become an imposing and effective obstacle on one of the main migration routes to Fortress Europe, thus sparing it the prospect of "invasion".

For more than a couple of decades, the region has become a polygon in which the EU can try out its state-building policies. This has resulted in a series of semi-protectorates faking democracy in political terms, ${ }^{22}$ while after its unconditional surrender to economic neoliberalism it can aptly be described as a sub-periphery in socio-economic terms. Srećko Horvat and Igor Štiks give an excellent regional diagnosis on what they call the "desert of post-socialism":

In spite of the rhetoric of incompleteness, we can observe that the free market reigns supreme; post-socialist Eastern Europe is fully incorporated into the capitalist world in a semi-peripheral role. In practice this means the availability of cheap and highly educated labour in proximity to the capitalist core, a quasi-total economic dependence on the core and its multinational banks and corporations, and finally the accumulation of debt. ${ }^{23}$

What is common to all these societies is that the public space has been squeezed, while their peoples became depoliticized (i.e. politics has become irrelevant). Michael Pugh's research 
Vol. 7, No. 1, 71-88.

has convincingly shown how the public arena in many post-Yugoslav polities has been increasingly strangled by monetarism, privatization, and limitation of the State's economic role. ${ }^{24}$ Genc Ruli described external state-building efforts as building "democracy without citizens" or "democracy without politics". 25 The Balkan societies have become pawns in a neoliberal economic agenda as part of a civilizing mission to bring "liberal peace" to war-torn countries, making them both vulnerable and helpless in the process. ${ }^{26}$ Having invested all their efforts in security sector reform in order to achieve their key strategic goals (i.e. NATO and EU membership), they all followed the neoliberal medicines, which meant more austerity, cuts in the welfare system, public-private partnerships, and privatization. In practice, these States gradually gave up the old socialist universal health system. Medical staff (nurses and physicians) have been emigrating in droves to more developed countries, Croatia being only a first stop on the way to their final destination: Germany and beyond.

The "white coats" (or what few of them have stayed in their home countries) have all of a sudden became indispensable public heroes, and even celebrities in some cases due to their media exposure. Struggling political leaders afflicted with diminished legitimacy and popularity could take advantage of the situation, claiming that "their policies and cadres won a victory over the pandemic". Interestingly, the health systems of former socialist States (in the Western Balkans but also in some EU countries of Central and Eastern Europe) showed much better results than their counterparts in old democracies to the west and north. On the territory of ex-Yugoslavia there have been certain institutional and expert memories of dealing with similar situations (such as smallpox - variola vera - in the 1970s). Despite fundamental weaknesses in almost all spheres, for the time being it seems that the Western Balkan countries have indeed coped relatively well, despite the fact the pandemic caught them unprepared. With the privatization of health services now almost complete, what remained of the public medical sector was underfunded, and mostly reserved for the underprivileged. This dual-track system meant that anyone who wanted to survive even relatively simple surgery or childbirth would not take the risk of going to a public hospital; the last pennies would be spent on treatment in private (more modern and successful) hospitals for the sake of life preservation. But the spread of the virus and the influx of so-called guest workers (gastarbeiters) returning from EU countries (mostly Italy, Austria, and Germany) after the onset of the pandemic, alerted governments to mobilize all public capacities. Aware of their inherent weaknesses, they had to turn to their "Western allies" (as NATO and the EU are usually dubbed) for help. After the cold shoulder they got from Brussels and (even worse) from Berlin, each country had to seek out readily available sources of assistance and/or purchase elementary medical equipment on its own. For instance, as a NATO/EU member-state, Croatia (just like Greece) could ask for Chinese (and Russian) assistance without fear of being "seen as disloyal by the Western power centres". In sharp contrast with its specific (neutral) foreign policy line, the Serbian leadership launched into an "offensive" towards its Eastern allies while overtly censuring Western hypocrisy. Macedonia proved the most obedient satellite of the West. Actually, while huge amounts of Chinese assistance arrived on a daily basis in Rome, Zagreb, Belgrade, and Athens, the Macedonian Foreign Minister was shyly sending requests to the Chinese embassy in Skopje but all efforts were of little or no avail. On the other hand, even the most modest and wretched assistance from the EU was vociferously announced, almost as if it were crucial. ${ }^{27}$

With no intention to go deeper into analysis of how much Western Balkan countries benefited from this so-called COVID-diplomacy (as the "information war" affects the reliability of sources, depending on where they come from and for what purpose), one can confidently conclude that geopolitical games of influence in the Balkans have not been on hold even during the worst of times. The initial EU decision not to offer assistance to the candidate countries was changed under public pressure ${ }^{28}$ and due to geopolitical concerns, so these countries eventually received some symbolic financial assistance. For instance, on 
22 April 2020 the EU Ambassador to Macedonia, Samuel Žbogar, tweeted that "North Macedonia will receive assistance via the EU Civil Protection Mechanism, including 5 generators, 25 family tents, 200 mattresses, 1000 blankets. Austria is also sending gloves and disinfectant among other things." This was met with a mocking slogan "A blanket for you", paraphrasing the 2018 name change campaign's slogan "EU for you". Among the exaggerated negative reactions, some pointed out the different treatment of the Western Balkan countries in their tweet responses: "EU donation for Serbia: one airplane with medical supplements. EU donation for Albania: 20,00o covid-19 tests. EU donation for Macedonia: family tents and blankets".

It was an irony of fate that Macedonia (now renamed North Macedonia after a dubious geopolitical intervention to satisfy Western interests in the region) ${ }^{29}$ became the 3oth member of NATO during the pandemic. Not only were the celebrations cancelled but, under the declared state of emergency, Macedonian soldiers engaged in keeping order in front of grocery stores and banks jam-packed with elderly people, or even in unconstitutional police arrests of people who had violated the curfew.

Another example to prove this hypothesis was the fact that the long-delayed decision to open accession talks with Macedonia and Albania was adopted - out of fear that other geopolitical actors may take advantage and exert their influence - on 24 April 2020 amidst serious criticism of EU mismanagement of the pandemic and lack of solidarity with its most affected member-states. European Commission President Ursula von der Leyen declared:

The European Union delivers on its promise. North Macedonia and Albania did what was asked of them and they have continued making progress with the reforms needed. Today marks the start of the journey to a bigger and stronger European Union. And this decision is in the European Union's geostrategic interest.

Commissioner for Neighbourhood and Enlargement Olivér Várhelyi was even more explicit: “Today's decision confirms the geostrategic importance of the Western Balkans and demonstrates that Europe is willing and able to take geopolitical decisions even in these trying times of corona virus pandemic." ${ }^{\circ}$ A more insightful analysis, however, shows that the decision was meant to have a mere placebo therapeutic effect: it was supposed to pacify worried citizens while the EU could claim moral and geopolitical victory. Bechev rightly argues that despite the good news, the Western Balkans are in trouble due to long-lasting problems in the socio-economic and political spheres. ${ }^{31}$ This Corona-diplomacy, nevertheless, further highlights not only the Union's lack of vision but also the deep internal divisions among EU countries. ${ }^{32}$

According to media reports, the key intention behind this decision was to prove that the EU remains operational and vigilant in the face of growing influence in the Balkans from rival powers such as Russia, Turkey, and China. ${ }^{33}$ The alleged green light still does not mean a concrete opening of the accession talks, so that Macedonia's predicament as a tantalized hopeful standing on the threshold may not be solved soon. The gist of the EU decision is that there might be an opening of the negotiation talks by the end of 2020 , with no clear date when and under what conditions it would come about. In the meantime, Bulgaria did not miss the chance to send a clear message that its blackmail is still on the table: the negotiation agenda for the first interstate conference must include the Bulgarian identity demands, i.e. denial of the Macedonian minority's existence as well as of a separate Macedonian language, among other things. ${ }^{34}$ Being located on the global fault-lines in geopolitical terms, Macedonia is part of a Balkan "turbulent frontier". ${ }^{35}$ From its onset, the EU accession process has been a means rather than an objective goal: troublesome States in the region (including Macedonia) were meant to be civilized and pacified after the Yugoslav imbroglio - yet not necessarily fully integrated. 
Vol. 7, No. 1, 71-88.

Seen from a foreign policy prism, even the pandemic has not changed the dominant political and intellectual discourse focused on the future of EU enlargement. While intellectual and academic circles try to challenge the capitalist mode of (re)production and thinking, countries like Macedonia, Bosnia, Serbia, Albania, and Kosovo are still thinking of their future in the EU family as if nothing had been going on there. It seems as if they are not even aware of the tectonic shifts on a global level, the shaking EU foundations, the redefinition of power relations, and especially the socio-economic problems that hang over them like a Damocles sword. Even the politically informed Croatian public was focused on the country's EU presidency in the first half of 2020, especially on the summit meeting which brought together EU member-states and the Western Balkan States. The conclusions reached at the Zagreb summit of 6 May 2020 sound as unreal as the way it was held: not a word about enlargement but new ultimatums (from Sofia) about an imagined identity dispute over the Macedonian language and Macedonian history. ${ }^{36}$ Still, the promised economic packages and loans are to be delivered by the end of the year.

\section{Responding to COVID-19 in the Western Balkans: (de)securitization for the sake of political gain?}

The insufficient attention paid to, or the lack of any meaningful preventive action against, the pandemic in its early phases (February/March 2020) were not a preserve of the European periphery. In the course of time, whenever Balkan governments ${ }^{37}$ were not sure what the right thing to do was, the usual response was a "copy-and-paste" operation, which brought them in line with the dominant options in Western countries, or in the neighborhood.

The pandemic was gradually "imported" - or better, spilled over from the west and north (i.e. from Italy and other European States where returning guest workers from the Balkans had been employed). In other words, both imported state-building medicines and the virus came from the same place - Europe; understandably, the response of weakened Balkan State systems was not as efficient as elsewhere on the continent. The first reactions of the political elites inclined more towards de-securitization because of the general disorientation and ineptitude of State apparatuses and health systems. While border controls and medical checks on arrival failed to prevent the virus from spreading, the authorities tried to downplay the threats and assure the population that they were prepared for any situation. Most indicative in this regard was the Serbian case: at first, the authorities spoke of a "funny virus" and an "ordinary flu", while a month later they claimed victory over COVID-19. ${ }^{8}$ The key person in the country's top medical team (Nestorović) advised women to go shopping in Milan (by then emptied). As things soon became too serious for jokes, the securitization process started at full force.

The state of exception/emergency was declared either formally (in Serbia and Macedonia) or informally (in Croatia, for example). Each case differed in formal and political terms, however, in Macedonia, such a declaration was mostly motivated by the need to postpone the elections called on 12 April. At the time, political and judicial institutions took a back seat and were silenced. New (mostly unconstitutional) hybrid bodies with blurred political and security powers were installed to deal with the crisis, i.e. to decide on human rights restrictions and on life and death issues.

President Vučić declared a state of emergency in Serbia on 15 March 2020, overtly side-stepping the parliament's role. In an address to the nation he used words connoting the deterrence strand of securitization, i.e. securitizing future developments: "accept that $\mathrm{X}$ is done in order to repel threat Y". ${ }^{39}$ Just ten days later the control strand of securitization was showcased, along with the authoritarian features of his crisis management, as noted by some observers. ${ }^{40}$ President Vučić's speech act this time clearly pointed to an existential threat: 
he issued a warning that Serbia could suffer as much as Italy. Furthermore, he used nationalistic emotive language, framing COVID-19 measures as acts of gratitude to protect the older generation who built the Serbian nation-state..$^{41}$ Actually, unlike other leaders in the region, having got involved in matters far removed from his domains of (in)competence, Vučić tried to overshadow medical teams by demonstrating how to use medical equipment or promising that soon a vaccine would be available in Serbia. In sum, he lived up to his previous role as a political clown (very much like Donald Trump), now in a new setting; the circumstances had changed but the Serbian superman remained unchallenged. ${ }^{42}$ The pandemic only served as an accelerator of something that had existed before. The alleged victory over the pandemic was meant to be immediately translated into a political (electoral) victory. ${ }^{43}$ Vučić's first virtual political rally had a dystopian taste to it. He spoke in front of over 50 large monitors where the audience (linked by Zoom) frenetically applauded the beloved leader: 1984 met 2020. Few believe that this will be a unique example, and that many other leaders would reject use of these tools to "meet" the voters and conduct other virtual electoral campaigns. The state of emergency in Macedonia was declared just three days after Serbia, i.e. on 18 March, also by the President of the Republic. However, the political situation and the securitizing agents here differed a lot from the Serbian ones. The country found itself in a unique situation: the pandemic came to its doorstep precisely at the time when Parliament dissolved itself for the sake of early elections. According to recent amendments to the Electoral code (introduced after a prolonged political crisis, the so-called "Colourful revolution" and consequent regime change of 2016), a hundred days before the elections the Prime minister is supposed to resign and be replaced by a caretaker Prime minister, and a couple of ministers and deputy ministers from the main opposition party, as part of a "technical" government. According to the so-called Pržino rules, ${ }^{44}$ the Interior Ministry is run by a candidate nominated by the opposition. Under such circumstances the Macedonian government could not speak in unison, and there appeared different securitizing agents with contradictory voices and proposals depending on the power imbalance within the technical government. The state of emergency declared for a 30-day period was inter alia meant to "resolve" the political endgame. Since the elections had to be postponed, the only legal way-out was a state of emergency. Initially, the hotspot of COVID-19 was in the small town of Debar, and it was dealt with in accordance with the Law on Crisis management, which envisages restrictions on certain human rights, a curfew, and use of army personnel alongside the police. The political opposition actually opted for an extension of the existing "state of crisis" (in accordance to the Crisis Management Law), instead of a state of emergency, but the ruling parties' will prevailed. The addresses to the nation of President Pendarovski, whose real power and influence are much weaker than Vučić's, were more nuanced and well-balanced due to the dual (political cum pandemic) reasons behind the state of emergency. ${ }^{45}$ Yet, he referred to "the deadly opponent" and pleaded: "we have to save our lives and help the helpless and the elderly". ${ }^{6}$ Having been closer to the ruling Social Democrats, he tried to send calming messages and incite trust in the government, which de facto concentrated all powers and started ruling by decree with no parliamentary, or even judicial, review. The conservative opposition was forced to criticize the government, but not too harshly, both because of a possible boomerang effect and the participation of "its own" minister of police. As for the securitizing measures, the general impression is that Serbia and Macedonia did not differ that much: with long curfews (some of which lasted three or even four days in total), announcements of lockdown just hours before it took effect (thus creating panic and chaos among the population), counterproductive measures regarding the schedule of the return to freedom of movement for different age groups, a list of contradictory messages, and manipulations on the number of tested and infected people, etc. Literally overnight, the Minister of Health became the most popular politician, despite his dubious political past and affairs in his recent political record. ${ }^{47}$ According to the survey conducted 
Vol. 7, No. 1, 71-88.

by the "36o degrees" media in early May 2020, as many as 78.5 percent of the respondents expressed their trust in the minister, and almost the same percentage (72) believed that the prescribed measures were adequate. ${ }^{8}$ Not a single politician or political leader has ever enjoyed such high trust in a minister or an institution, which goes to prove that, despite fear and rather draconian and unconstitutional measures in time of crisis, the citizens badly need authority, guidelines, and someone to trust in the face of lethal danger. The Macedonian minister, a medical doctor and university professor, managed to inject both calmness and a feeling of security, even though objective figures show that Macedonia tops the list of countries with the highest death-toll in the region (including Kosovo and Bosnia-Herzegovina). A few scholars and intellectuals raised their voices against the strict restrictions on freedom of movement and reduction of other human rights under the state of emergency, but obviously the general public does not agree with them. Out of fear, a polarized public has shown quite a degree of animosity toward those who do not respect the protective measures; cries for harsher measures and punishment as well as for extending the lockdown, etc., are heard quite often. On the other hand, the analyses published in this period also have been somewhat biased along political lines: they have noticed shifts towards authoritarianism, but the blame for this has only been laid on the Minister for Police Affairs (i.e. the representative of a party still seen as dictatorial among those in intellectual circles who joined the Colourful revolution that precipitated the 2016 regime change). .9

Despite the apparently rigid lockdown measures, the government's inconsistent behavior and decisions de facto showed that the weak State had been held hostage to business and lobby groups representing some of the richest people in the country, but also to the religious communities. During the lockdown period (April-May 2020, mostly), Macedonia had to deal with two major religious holidays (Easter and Ramadan), not to mention a few minor ones. Not only did the State on the ground prove the point made long ago by philosopher Michel de Certeau - "When the political withers, the religious reawakens" but also proved the fact that State institutions and the bans they institute were a mockery as long as the law enforcement system remained totally impotent. Even the most popular politician (the minister of Health) could only express his personal disappointments and appeal to people's common sense. A couple of times the planned restrictive measures were modified at the insistence of political parties dependent on religious leaders. An esteemed medical doctor rightly argued that as people got tired of the government's extensive, controversial, and variable measures, the State has taken a backseat to religious institutions enjoying much higher reputations and influence on believers. De facto, they occasionally surface as key (de)securitization agents. For instance, in order to extort budget funds for his community, Reis-ul-ulema Sulejman Rexhepi warned the government that without its assistance the followers of Islam would ignore the State's measures and rush to the mosques, which would turn Macedonia into Bangladesh. On the eve of Ramadan, however, he triumphantly sent a message to his religious followers in which he declared "the virus dead once for all".$^{50}$ Furthermore, as the date of parliamentary elections approaches, religious leaders assert their influence on political elites through blackmail ultimatums over the political loyalty of their followers. At the end of the day, stuck between weak State institutions bereft of legitimacy and religious demands, the undisciplined and illiterate citizen has to take the blame for the spread of the pandemic.

The pandemic and the fierce lockdown measures introduced to stem it provided ideal opportunities for the ruling regimes to secure gains in various matters. For instance, the urban mafia got a free hand: government in Albania allowed the demolition of the old theatre house; ${ }^{51}$ in Macedonia, the famous Old Bazaar from Ottoman times, a valuable cultural heritage, was opened tenders for alleged "renovation"; 52 the devastation of natural resources and the free ride offered to foreign corporations continued, 53 etc. Socio-economic responses to the pandemic's effects have also been controversial on various levels. 
Firstly, they displayed a lack of any emergency planning on the part of the affected Balkan States. While populist measures (mostly promises) were being introduced to keep the population's lower strata quiet, huge amounts of money have been pumped into the big businesses of tycoons close to (or part of) ruling elites. Most importantly, there is no strategy for dealing with the disastrous effects of the crisis in the medium and long term: everything is focused on gaining a majority in the forthcoming parliamentary elections. The dependency syndrome and inertia of short-sighted elites who pin all their hopes on the assistance Western powers (and financial institutions) may or may not provide had been a constant in pre-corona times, and have only redoubled during the present health crisis. Indeed, these countries' national debt has been continuously growing and new loans are announced. However, the proposed socio-economic "packages" have mostly appeared to be a "legalized" bribery of the poorest parts of the population by the ruling parties in the guise of "humanitarian aid for those affected by the pandemic".

Three of former Yugoslavia's successor states (Croatia, Serbia, and Macedonia) are preparing for parliamentary elections. While on the face of it significant differences may seem to exist between them in terms of international status, economic development, and political regimes, the circumstances created by the pandemic showed that they are not so different after all: in all three countries, the leadership has been using similar securitizing tactics in order to impose discipline, and their top medical teams have gained legitimacy, but also disciplinary power, which proved useful for the politicians who stood behind them or by their side. Once the economic and political motives and interests that hitherto prevailed began to change, what used to be portrayed as a deadly danger (or even a form of bioterrorism) all of a sudden became a tolerable risk in anticipation of forthcoming elections. Each ruling elite seems willing to take advantage of the situation in order to gain politically, despite denunciations of such moves as not quite democratic by political opponents, and an unsafe environment for the voters. The calculation is simple: the costs of the pandemic and "stay-at-home" practices will soon prove too high - recession is on its way and political elites have no clue how to deal with it. As a result, they play it both ways. In order to persuade the electorate that it is quite safe to do things that, until recently, were deemed a form of bioterrorism, they (along with their economic partners) use classical "gaslighting", which is a form of de-securitization. Internet memes present that quite wittily: a member of a crisis HQ team advises the public that from now on any symptom such as cough or fever will be treated as an ordinary flu. On the other hand, whenever an opponent advances public health reasons for delaying the elections, the response is again in the form of securitization: "the second wave of COVID-19 would be terrible, and don't let's delude ourselves: it is waiting just around the corner". Or simply: "you cowards don't want to take up the political challenge of the next elections!"

In line with global tendencies during the pandemic, the Western Balkan States' existing political, institutional, societal, and economic deficiencies and ruptures have been exacerbated. The securitization/de-securitization game has always been part of the Balkan political landscape: regardless of the occasion, promises of a bright future go hand-in-hand with fearmongering. If things cannot be achieved through persuasion and "normal politics" (based on unrealistic promises), the other option is to play on the emotions and basic fears of impoverished and insecure populations. The fact that the politics vs. security distinction (whether the latter is construed as human, military, economic security, or other) is often blurred actually proves the validity and applicability of securitization theory. Quite often the so-called "international community" appears as the key securitizing agent, arguing why something is to be treated as a security issue ${ }^{54}$ in this or that circumstance - and when that is not a good idea. 
Vol. 7, No. 1, 71-88.

\section{By way of conclusion: no visions of a post-COVID-19 world in the Western Balkans}

Starting from the premise of a superimposition of the COVID-19 crisis on the pre-pandemic agenda of unmet societal, economic, ecological, and ethical challenges of global scope that were irresponsibly evaded and denied, this article moved to one corner of Europe that has also been geopolitically quarantined.

At first glance, it seems as if the weak Western Balkans countries dealt rather successfully with COVID-19 but fell victim to authoritarian tendencies induced by the pandemic. According to a number of think tank and watchdog organizations, crisis management modalities showed serious problems there (including Croatia, a former member of this artificial region). ${ }^{55}$ While they correctly list such factors as excessive powers vested in the executive branch; personalization of rule; small-time dictators and nationalists trying to benefit from the common misfortune; and petty profiteers, not to mention a normalization of states of exception, violation of basic human rights, and selective measures and law enforcement depending on the social, ethnic, or religious group, their key concerns are on the damaging effect of Europeanization, i.e. EU relations and influence. They regularly pay attention also to (allegedly) increased Chinese influence on what is seen as a European sphere of interest. In short, most of them remain loyal Eurocentric supporters in times of pandemic and their advice concerns the furthering of EU integration prospects for these countries, which is no surprise when one has in mind who the donors behind these surveys and projects are. The findings of all these studies rightly point out that there are increased authoritarian trends, human rights and freedoms are seriously endangered (particularly the rights to privacy, freedom of speech, movement, and gathering), media freedoms are reduced by censorship or self-censorship, etc. Their main problem is lack of contextualization. The so-called Western Balkans region has been a patient undergoing European state-building treatment for decades, and many already agreed that the therapy not only failed but had iatrogenic effects. Can the Western Balkan States/leaderships/citizens be blamed for the logical outcomes of such medicines amidst a global pandemic? Even if the answer is positive, one should be aware that they have developed habits and learnt quickly from their Western mentors on how to use surveillance (capitalism), how to take advantage of disasters, how to privilege rich over poor, how to increase social inequalities, how to facilitate marriages between political, business, and media elites, how to pacify intellectuals and scholars ("catmanism"), how to bribe NGOs, how to keep clientelistic power relations, etc. It is hard to scold the good (or not so good) pupils when they master the disciplines where their teachers/ preachers excel.

So far, we all know that COVID-19 is highly contagious, but the virus is not the only agent in the contamination business. The periphery is hardly able to secure a true image of the pre-corona world, and much less offer a better vision for the post-corona world. The powers that be have swiftly embraced the phrase of "new normalcy" as part of their everyday vocabulary. The same is true even in those among peripheral countries where originally English phrases sound bizarre, which only proves that they were simply imported by inertia or by an instinct of submissive discipline. ${ }^{6}$ Regardless of its meaning (known to very few), the discourse of "new normalcy" opens up enormous space for improvisations and cover-ups of all measures allegedly taken for the sake of common good, but in reality to satisfy power or economic interests. While parroting the phrases that are popular in a rapidly changing world's elite circles, the Balkan periphery is still in limbo, thinking that all that matters is what Brussels (or Washington) thinks of them and how it will be rewarded for its loyalty (in relation to their global rivals). At the same time, there is a sort of intellectual eclipse about ongoing global turbulences that are visible to observers in core countries: there is talk about 
the EU's shaken foundations, turbocharged failures, and Euro crisis; international horizons thunder, there is spectre of military conflict between the US and China, and global famine may affect a huge part of human population, etc. Dominique Moïsi rightly points out that this crisis has mainly demonstrated Germany's strength rather than Europe's resilience. ${ }^{57}$

It sounds surreal to probe small talk on the periphery about European prospects at a time when others are considering new portals for a better world. Or predict apocalypse. The Balkans dream a little dream of joining their rich relatives in the European Union. The news is that the poor region's economies are expected to suffer from the fallout of the pandemic as elsewhere in Europe. "The Balkans will face the same difficulties, only worse, once the pandemic ends" is a typical media headline. Yet the problem is that the very same headline applies equally well to the entire world.

\section{Notes}

'Prof. Biljana Vankovska is a political scientist and peace researcher who teaches at the Faculty of Philosophy, Ss. Cyril and Methodius University in Skopje, Macedonia. She is also editor to the scholarly journal Security Dialogues. Email: biljanav@fzf.ukim.edu.mk.

${ }^{2}$ Arundhati Roy, "The pandemic is a portal", Financial Times, 3 April 2020, available at https://www.ft.com/ content/1od8f5e8-74eb-11ea-95fe-fcd274e920ca (accessed on 17 May 2020).

3 Vassilis K. Fouskas and Bulent Gokay, "COVID-19 and the bankruptcy of neoliberalism in the context of Global Shift", Open Democracy, 5 May 2020, available at https://www.opendemocracy.net/en/can-europemake-it/covid-19-and-bankruptcy-neoliberalism-context-global-shift/ (accessed on 17 May 2020). Also, Vassilis K. Fouskas, Bulent Gokay, and Biljana Vankovska, "Crisis in the eastern Mediterranean and COVID19", Journal of Balkan and Near Eastern Studies, 22(3), May-June 2020.

${ }^{4}$ The Oxford scholar Sunetra Gupta put it this way: “. . . the truth is that lockdown is a luxury, and it's a luxury that the middle classes are enjoying and higher income countries are enjoying at the expense of the poor, the vulnerable and less developed countries". (Freddie Sayers interview with Sunetra Gupta, "COVID19 is on the way out", UnHerd, 21 May 2020, available at https://unherd.com/2020/o5/oxford-doublesdown-sunetra-gupta-interview/ (accessed on 22 May 2020).

${ }^{5}$ For an overview of a very interesting polemic, see: M. Foucault, G. Agamben, J.L. Nancy, R. Esposito, S. Benvenuto, D. Dwivedi, S. Mohan, R. Ronchi, and M. de Carolis, "Coronavirus and philosophers", European Journal of Psychoanalysis, April 2020, available at https://www.journal-psychoanalysis.eu/coronavirusand-philosophers/ (accessed on 17 May 2020).

${ }^{6}$ Kenneth Burke (1984), Permanence and change: an anatomy of purpose. University of California Press, Berkeley, p. 49.

7 In his recent text entitled "Medicine as Religion", Giorgio Agamben argues that science has become the religion of our time, especially in the West where it leads ahead of the other two religions (Christianity and capitalism). In his view, "It is not surprising that the protagonist of this new war of religions should be that part of science where the dogmatic is less rigorous and the pragmatic aspect stronger: medicine, whose immediate object is the living body of human beings." (An English translation by Adam Kotsko is available at https://itself.blog/2020/05/o2/giorgio-agamben-medicine-as-religion/ (accessed on 17 May 2020). However, Agamben speaks of Medicine as if it were one coherent entity (vs. its competitors). Medical doctors and researchers have never been so exposed to media as in the last months; yet, their findings and medical advice differ enormously so the general public is often indeed in a situation to try to "believe" one or another medical strategy. The academic fast-track publishing in the most respectable journals (where usually it takes months if not years to get an article published) is another aspect of the problem of (mis)use of academia and medicine by the State officials.

${ }^{8}$ M. Foucault, G. Agamben, J.L. Nancy, R. Esposito, S. Benvenuto, D. Dwivedi, S. Mohan, R. Ronchi, and M. de Carolis, ibidem.

9 Unfortunately, in the face of death itself (as if it had not been with us before) the tolerance for critical thinking has gone down even in academic and intellectual circles in the West, and even more so in its periphery. Respected Balkan intellectuals, such as Teofil Pančić or Boris Dežulović, to mention just a few, who dared criticize the government's measures and the general paranoia over COVID-19, have been immediately crucified and labelled "conspiracy theorists". 
Vol. 7, No. 1, 71-88.

${ }^{10}$ Michel Foucault (2003), "Society Must Be Defended": Lectures at the Collège de France, 1975-1976, trans. David Macey, New York: Picador.

"The scandal of Romanian workers exported to Germany to harvest the population's favorite vegetables speaks for itself, but pales in comparison with the even more scandalous treatment of Italy at the hands of its fellow EU-partners. See: Costi Rogozanu and Daniela Gabor, "Are western Europe's food supplies worth more than East European workers' health?", The Guardian, 16 April 2020, available at https://www. theguardian.com/world/commentisfree/2020/apr/16/western-europe-food-east-european-workerscoronavirus (accessed on 17 May 2020).

${ }^{12}$ Lately there has been harsh criticism of this theory that went so far as to blame its academic fathers for being racist. According to these critics, the theory is not only inapplicable outside of the Western democratic context, and thus exposed to a racist worldview. See: Alison Howell and Melanie Richter-Montpetit, "Is Securitization Theory Racist? Civilizationism, Methodological Whiteness, and Anti-black Thought in the Copenhagen School", Security Dialogue, 51(1), 2020. Fora response, see: "Peace researcher Ole Wæver accused of racism: 'I've never felt so bad about my life as an academic', University Post, University of Copenhagen, 15 May 2020, available at https://uniavisen.dk/en/prominent-peace-researcher-accused-of-racism-ive-neverfelt-so-bad-about-my-life-as-an-academic/?fbclid=IwARoCvh5-rxdpRMIavCvrdH3iBızYc_f_sDaizURSFTx92kNtEl5v4aaASo (accessed on 24 May 2020). Disregarding this unfounded criticism (and even the personal lynching that followed), one needs to be aware that this is not an isolated case, and that academic freedom is being seriously undermined from within - not only by power centres, as usual.

${ }^{13}$ Barry Buzan, Ole Waever, and Jaap de Wilde (1998), Security: A New Framework for Analysis, London, Boulder, Lynne Rienner Publishers, pp. 23-24.

${ }^{14}$ Ole Wæver, "Securitization and De-securitization". In Ronnie D. Lipschutz (ed.) (1998), On Security, New York, Columbia University Press, p. 45.

${ }^{15}$ Sears, N.A., "The Securitization of Covid-19: Three Political Dilemmas", Global Policy Journal, 25 March 2020, available at https://www.globalpolicyjournal.com/blog/25/03/2020/securitization-covid-19-threepolitical-dilemmas (accessed on 17 May 2020).

${ }^{16}$ WHO Director-General's opening remarks at the media briefing on COVID-19, 11 March 2020, available at https://www.who.int/dg/speeches/detail/who-director-general-s-opening-remarks-at-the-mediabriefing-on-covid-19---11-march-2020 (accessed on 17 May 2020). Also, WHO Director-General, Dr. Tedros, said that COVID-19 represents a "common enemy, an enemy of humanity", while UN Secretary-General, António Guterres, referred on his Twitter account to a common threat that no country can address alone.

${ }^{17}$ Maureen N. McLane, "From A Book of Hours", August 2019, available at https://poets.org/poem/bookhours?fbclid=IwAR3 Kl 75 M_8IrYDf7zDKACOpTarkzkYjexsN44PUbOyQVv9kmbXSNITEj-6g (accessed on 17 May 2020).

${ }^{18}$ Clive Archer (2015), International Organizations, 4th edition, New York, Routledge.

${ }^{19}$ Ronnie Olesker, "The Securitization Dilemma: Legitimacy in Securitization Studies", Critical Studies on Security, 6(3), 2018, p. 312.

${ }^{20}$ Julio Vincent Gambuto, "Prepare for the Ultimate Gaslighting", Forge, 10 April 2020, available at https:// forge.medium.com/prepare-for-the-ultimate-gaslighting-6a8cezfoaoeo (accessed on 21 May 2020). The follow-up article by the same author appeared on 1 May 2020 entitled "The Gaslighting of America Has Begun". The key message of his second article read: "Understand your power, my friends. Businesses and government do", available at https://forge.medium.com/the-gaslighting-has-begun-resist-aac3658813d4.

${ }^{21}$ Robert Cox, "Social Forces, States and World Orders: Beyond International Relations Theory", Millennium 10(2), 1981, p. 128.

${ }^{22}$ David Chandler (2006), Empire in Denial: The Politics of State-Building, London, Pluto Press. Also see Chandler's excellent description of Dayton Bosnia that equally applies to post-conflict Macedonia in light of the outcomes of its power-sharing system (Bosnia: Faking Democracy after Dayton, 2nd edition, London, Pluto Press, 200o.)

${ }_{23}$ Srećko Horvat and Igor Štiks (2014), Welcome to the Desert of Post-Socialism. Radical Politics after Yugoslavia, London, Verso.

${ }^{24}$ Michael Pugh, "Transformation in the political economy of Bosnia since Dayton", International Peacekeeping, 12(3), 2005, p. 449.

${ }_{25}$ Genc Ruli, "Albania: The Weakness of the State", in Wim van Meurs (ed.) (2003), Prospects and Risks Beyond EU Enlargement: Southeastern Europe: Weak States and Strong International Support, Opladen, Leske \& Budrich.

${ }^{26}$ Michael Pugh (ed.) (200o), Regeneration of War-Torn Societies, Macmillan, London. 
${ }^{27}$ On a special ceremony the caretaker Prime Minister Oliver Spasovski expressed the deepest gratitude to EU's assistance and expressed his assurance that coronavirus would be defeated if we all joined forces. See: "Republika Severna Makedonija pripaga na evropskoto semejstvo, EU vo ovaa zdravstveno-ekonomska kriza ja spodeli grizata i pomosta so nasata zemja kako da sme veke clenka" [Republic of North Macedonia belongs to the European family; in this health-economic crisis EU has shared concerns and assistance with our country as if we were already a member-state], Official statement, 9 May 2020, available at https:// vlada.mk/node/21349?ln=en-gb (accessed on 17 May 2020).

${ }^{28}$ Bender Kristof, Adnan Čerimagić, and Gerald Knaus, "EU Has Turned Enlargement into a Hamster Wheel”, Balkan Insight, 15 January 2020, available at https://balkaninsight.com/2020/o1/21/eu-has-turnedenlargement-into-a-hamster-wheel/ (accessed on 17 May 2020).

${ }^{29}$ Biljana Vankovska, "Geopolitics of the Prespa Agreement: Background and After-Effects", Journal of Balkan and Near Eastern Studies, April 2020, 22(3), pp. 343-371.

$3^{30}$ Press release, "Commission welcomes the green light to opening of accession talks with Albania and North Macedonia", 25 March 2020, available at https:/ec.europa.eu/commission/presscorner/detail/en/ IP_20_519 (accessed on 17 May 2020).

${ }^{31}$ Dimitar Bechev, "Despite good news, the Western Balkans are in trouble", Al Jazeera, 1 April 2020, available at https://www.aljazeera.com/indepth/opinion/good-news-western-balkans-trouble-200401155854613.html (accessed on 17 May 2020).

${ }^{32}$ Aleksandar Ivković, "Perception of EU aid amidst the pandemic faces challenges across the Western Balkans", European Western Balkans, 17 April 2020, available at https://europeanwesternbalkans. $\mathrm{com} / 2020 / 04 / 17 /$ perception-of-eu-aid-amidst-the-pandemic-faces-challenges-across-the-westernbalkans/ (accessed on 17 May 2020).

33 Jacopo Barigazzi, "North Macedonia, Albania get green light for EU membership talks", Politico, 25 March 2020, available at https://www.politico.eu/article/north-macedonia-albania-eu-membership-talks/ (accessed on 17 May 2020).

34 The full text of the Bulgarian demands was kept hidden from the Macedonian public until the Austrian parliament published the document on its website, available at https://www.parlament.gv.at/PAKT/EU/ XXVII/EU/o1/66/EU_16606/imfname_10969905.pdf (accessed on 17 May 2020).

35 According to the concept of "turbulent frontier", the best defence is an offensive strategy. This view asserts that cumulative gains in the imperial periphery can be reaped through aggressive action, whereas passivity will bring cumulative defeats. Galbraith explains that the solution to security problems at the "turbulent frontier" of the empire is to conquer still more territory in order to punish or prevent harassment by contiguous barbarians. (See: Galbraith S. John, “The 'Turbulent Frontier' as a Factor in British Expansion,” Comparative Studies in Society and History, 2(2), 1960. This position was paraphrased by the US State Secretary John Kerry in February 2015. He told the Senate foreign affairs committee that "Serbia, Kosovo, Montenegro and Macedonia are the new frontline between Russia and the West" (Jean-Arnault Dérens and Laurent Geslin, "No holds barred in revived cold war. Balkans are the new frontline", published in Le Monde Diplomatique, July 2015, available at https://mondediplo.com/2015/07/04balkans (accessed on 3 May 2020)).

36 "In the fight against COVID-19, the European Union and the Western Balkans are united", available at https:// www.consilium.europa.eu/en/meetings/international-summit/2020/05/06/ (accessed on 20 May 2020).

37 In this section, the analytical focus is primarily on Serbia and Macedonia, with a few references to Croatia and Albania.

$3_{8}$ "Posle kampanje 'Ovo je smešni virus', dolazi kampanja 'Pobedili smo smrtonosni Covid-19”' [After the campaign 'This is a funny virus' a new campaign is coming 'We conquered lethal covid-19], OzonPress, 20 April 2020, available at https://www.ozonpress.net/politika/posle-kampanje-ovo-je-smesni-virus-dolazikampanja-pobedili-smo-smrtonosni-covid-19/ (accessed on 20 May 2020).

39 Juha A. Vuori, "Illocutionary Logic and Strands of Securitization: Applying the Theory of Securitization to the Study of Non-Democratic Political Orders", European Journal of International Relations, 14(1), 2008, p. 8 o.

$4^{40}$ Milica Vojiović, "Serbia COVID-19 Lockdown Takes an Authoritarian Turn", OCCRP, 25 March 2020, available online at: https://www.occrp.org/en/daily/11992-serbia-s-covid-19-lockdown-takes-an-authoritarianturn (accessed on 20 May 2020).

${ }^{41}$ Eves Lewis and James Thedham, "Applying Securitization's Second Generation to COVID-19", E-International relations, 14 May 2020, available at https://www.e-ir.info/2020/05/14/applying-securitizations-second-generation-to-covid-19/ (accessed on 20 May 2020). 
Vol. 7, No. 1, 71-88.

${ }^{42}$ The same observation is shared by some intellectuals over the Albanian Prime Minister's role. In a video talk, which is a part of a series "COVID-19 Western Balkan Dialogue" run by BiEPAG and the Centre for Southeast European Studies, Genthiola Madhi (Research Associate at Osservatorio Balcani e Caucaso Transeuropa) expressed the dilemma in Albania's public seeing daily press conferences of Edi Rama: "Are there any experts? Is he the sole actor who makes decisions and knows everything?" Available at https:// www.youtube.com/watch?v=CwVYASdTBSE (accessed on 20 May 2020).

${ }^{43}$ The elections are supposed to take place on 21 June 2020, and the opposition is strongly opposed and threatens the government with a boycott.

${ }^{44}$ The Pržino agreement (2 June-15 July 2015) mediated by EU ended the first stage of the 2014-15 political crisis that resulted in the ousting of strongman Nikola Gruevski from power. The consequent amendments to the Electoral Code are still in force. Former Prime Minister Zoran Zaev called for early elections after the EU Summit held in October 2019 because of its failure to keep the promise of starting accession process after the heavy price the country had paid in exchange for it - the name/constitution change in 2018/19. Zaev resigned in early January, and parliament was dissolved in mid-February 2020. The elections were planned for 12 April, but COVID-19 affected the plans.

${ }_{45}$ Decree on State of Emergency - Addressing remarks by President Pendarovski, Press Release, 18 March 2020, available at https://pretsedatel.mk/en/decree-for-state-of-emergency-addressing-remarks-bypresident-pendarovski/ (accessed on 20 May 2020).

${ }_{46}^{6}$ President Pendarovski: Self-isolation is the best prevention against COVID-19, Press Release, 24 March 2020, available at https://pretsedatel.mk/en/president-pendarovski-self-isolation-is-the-best-preventionagainst-covid-19/ (accessed on 20 May 2020).

${ }_{47}$ Venko Filipče used to be close to today's opposition (i.e. he was a special adviser to the Minister of Health in strongman Nikola Gruevski's Cabinet). As an acting minister in the government of Zoran Zaev, he is remembered for a few scandals and mostly for his proposal for further privatization of the health system (i.e. emergency care, city hospital, and clinical labs) through public-private partnerships and/or outsourcing. See: "Vladata saka vo GOB '8 septemvri', itnata pomoš i PET centarot da vleze privaten partner" [The Government wants a private partner to get involved in the City General Hospital '8 September' and PET Center], SDK, 28 May 2018. "Privatizacija na brzata pomoš ima logika, veli fizibiliti studijata, Filipče najavi javna rasprava" [Privatization of emergency care system is logical, finds a feasibility study; Filipče announced public debate], 365.com.mk, 13 September 2020, available at https://365.com.mk/302264/privatizatsija-na-brzata-pomosh-ima-logika-veli-fizibiliti-studijata-filipche-najavi-javna-debata (accessed on 20 May 2020).

48 "Anketa na "Detektor": Ostanuva visokata doverba na gragjanite vo ministerot Filipče" [Opinion Poll on "Detector":The trust of citizens in minister Filipčeremains high], 36o Degrees, availableat https://36ostepeni. $\mathrm{mk} /$ anketa-za-detektor-ostanuva-visokata-doverba-na-graganite-vo-ministerot-filipche/ (accessed on 20 May 2020).

${ }^{49}$ See, for instance: Katerina Kolozova, "Demokratijata na zadno sedištevo vreme na pandemija" [Democracy takes a backseat in time of pandemic], Res Publica, 11 May 2020, available at https://respublica.edu.mk/ blog/2020-05-11-08-17-27 (accessed on 20 May 2020).

5o See: "A day after Islamic Community head threatens to 'turn Macedonia into Bangladesh', the Government caves in, pays him off", Republika, 10 April 2020, available at https://english.republika.mk/ news/macedonia/a-day-after-islamic-community-head-threatens-to-turn-macedonia-into-bangladeshthe-government-caves-pays-him-off/ (accessed on 26 May 2020). Also: "Reis Rexhepi declares victory over the coronavirus even as fears grow that the Ramadan celebrations will lead to a new spike", Republika, 24 May 2020, available at https://english.republika.mk/news/macedonia/reis-rexhepi-declares-victoryover-the-coronavirus-as-fears-grow-that-the-ramadan-celebrations-will-lead-to-a-new-spike/ (accessed on 26 May 2020)

${ }^{51}$ Gentiola Madhi, "Albania: The end of a theatre", OBCT, 18 May 2020, available at https://www.balcanicaucaso.org/eng/Areas/Albania/Albania-the-end-of-a-theatre-202034 (accessed on 20 May 2020).

${ }^{52}$ See: Donka Bardzieva Trajkovska, "Nova stara čaršija“ [New Old Charshia], 24 April 2020, Deutsche Welle in Macedonian, available online at https://www.dw.com/mk/\%Do\%BD\%Do\%BE\%Do\%B2\%Do\%Bo\%D1\%81\%Di\%82\%Do\%Bo\%Di\%8o\%Do\%Bo-\%Di\%87\%Do\%Bo\%D1\%8o\%D1\%88\%Do\%B8\%D1\%98\%Do $\%$ Bo/a-53215280 (accessed on 20 May 2020).

53 Inhabitants and activists of the southern Ilovica region had been fighting against the opening of a mine (dubbed "the Mine of Death" due to its harmful effects for the environment and human health) by the Canadian firm Euromax Resources. After a series of successful local referenda and collective actions on 
the ground, the Government decided to cancel the deal. What was seen as a great victory in October 2019, appeared to be a farce: the Administrative court ruled in favor of the company on 31 March 2020, during the state of emergency, but failed to make it public. See: "Macedonian Government still hasn't received the ruling of the Administrative Court about Ilovica Mine", Meta News Agency, 20 May 2020, available at https:// meta.mk/en/the-macedonian-government-still-hasnt-received-the-decision-of-the-administrative-courtabout-the-ilovica-mine/ (accessed on 25 May 2020).

${ }^{54}$ For instance, there was lot of securitization of the "name dispute" between Athens and Skopje as long as the issue had not been "resolved" through imposition of the highly controversial Prespa agreement. In reality, the agreement did not resolve anything but worsened the societal security dilemma within Macedonia and increased internal inter-ethnic and intra-ethnic divisions.

${ }_{55}$ See, for instance: Max Brändle et al., Democracy and the State of Emergency. Political Battles Emerging out of the Corona Crisis in the Western Balkans, Croatia and Slovenia, Report Two, Belgrade: FES Office, 18 May 2020; The Western Balkans in Times of the Global Pandemic, BiEPAG Policy Brief, April 2020. Frederico Caruso, "Not just apps: privacy, personal data and COVID-19 in the western Balkans", available at https:// www.balcanicaucaso.org/eng/Areas/Balkans/Not-just-apps-privacy-personal-data-and-COVID-19-in-thewestern-Balkans-201814 (accessed on 26 May 2020); Katerina Kolozova et al., The State of Democracy in North Macedonia in the Times of the COVID-19 Pandemic, Skopje, ISSHS, 2020, available at http://www. isshs.edu.mk/the-state-of-democracy-in-north-macedonia-in-the-times-of-the-covid-19-pandemic/ (accessed on 25 May 2020).

${ }^{56}$ For instance, the Macedonian caretaker Prime Minister Oliver Spasovski (a policeman by vocation) who hardly speaks any foreign language, suddenly started using the phrase in his regular press conferences. See the press conference held on 12 May 2020, available at https://vlada.mk/node/21366 (accessed on 17 May 2020). Serbian Prime Minister Ana Brnabić uses the same phrase. Also: "Brnabić: Ovo je naša nova normalnost", Novosti, 7 May 2020, available at https://www.novosti.rs/vesti/naslovna/drustvo/aktuelno.290. html:863499-Brnabic-objasnila-sta-je-nasa-nova-normalnost-Mere-ce-se-menjati-iz-nedelje-u-nedelju (accessed on 17 May 2020).

${ }^{57}$ Dominique Moisi, “The Déjà-Vu Virus?", Project Syndicate, 4 May 2020, available online at https://www. project-syndicate.org/commentary/covidı-policymakers-must-not-repeat-past-mistakes-by-dominiquemoisi-2020-05 (accessed on 26 May 2020). 